\title{
The use of the head louse as a remedy for jaundice in Spanish folk medicine: an overview
}

\author{
José Ramón Vallejo ${ }^{1 *}$ and José Antonio González²
}

\begin{abstract}
Background: In Spain, head lice are considered a therapeutic resource for the treatment of jaundice. All folk remedies based on the ingestion of these insects meet in the present document, previously dispersed among a large number of references.
\end{abstract}

Methods: An overview of the Spanish literature has been carried out. The most important databases have been consulted. All related works have been examined.

Results: Although the method of preparation is diverse and the dose varies, the primary recommendation is a transference ritual consisting of taking nine live lice for nine days on an empty stomach without the patient's knowledge. This traditional knowledge survives in Spanish society, and constitutes an example of the interrelation between Spanish and Latin American folk medicines.

Conclusions: The survival of this therapy in the worldview of certain rural communities suggests the need to take into account the beliefs, ideas and behaviour patterns of popular culture in relation to health and disease.

Keywords: Head louse, Jaundice, Ingestion, Traditional medicine, Spain

\section{Resumen (in Spanish)}

Antecedentes: En España, los piojos de la cabeza son considerados un recurso terapéutico para el tratamiento de la ictericia. Todos los remedios populares basados en la ingestión de estos insectos se reúnen en el presente documento, previamente dispersos por un gran número de referencias.

Métodos: Se ha llevado a cabo una revisión exhaustiva de la literatura española y han sido consultadas las bases de datos más importantes. Se han examinado todos los trabajos relacionados.

Resultados: Aunque el método de preparación es diverso y la dosis varía, la recomendación principal es un ritual de transferencia consistente en tomar nueve piojos vivos durante nueve días en ayunas y sin el conocimiento del paciente. Este conocimiento tradicional sobrevive en la sociedad española, y constituye un ejemplo de la interrelación entre las medicinas populares española y latinoamericana.

Conclusiones: La supervivencia de esta terapia en la cosmovisión de algunas comunidades rurales sugiere la necesidad de tener en cuenta las creencias, ideas y patrones de comportamiento de la cultura popular en relación con la salud y la enfermedad.

\footnotetext{
* Correspondence: joseramonvallejo@unex.es

'Departamento de Terapéutica Médico-Quirúrgica, Facultad de Medicina,

Universidad de Extremadura, E-06006, Badajoz, Spain

Full list of author information is available at the end of the article
} 


\section{Background}

Entomotherapy, understood as the use of insects or products derived from them for the treatment of human diseases [1], is currently one of the main focuses of ethnozoological research. Many authors have reported inventories of useful taxa, for example in Brazil more than 80 insect species are described [2], but they also document the importance of these animals in folk medicine, especially in rural areas. This is why research projects have been implemented in certain ethnic groups, human communities or cultures in which the use of medicinal insects and traditional knowledge about such species remain in force despite the risk of their attrition and risk of eventual disappearance $[3,4]$.

Jaundice is not a disease but an external sign of an underlying pathological process that interferes with the normal functioning of the metabolism and excretion of bilirubin [5-7]. However, since antiquity it has been described as such-see Blánquez 1966 [8]-and folk medicine has treated jaundice using a wide variety of remedies from time immemorial. In Spain, according to George M. Foster [9], there are three main methods of healing jaundice: urinating on certain plant species, watching the water running on the bank of a river or stream, and drinking water containing human lice (Pediculus humanus Linnaeus, 1758). Among organisms of this taxon of blood-sucking insects (Phthiraptera: Anoplura: Pediculidae), two subspecies are differentiated: P. humanus humanus Linnaeus, 1758 (the body louse) and P. humanus capitis De Geer, 1778 (the head louse) $[10,11]$. Populations of these two lice can be separated based on a few morphological features, but mostly on the basis of certain behavioural and ecological differences. Head lice live and feed exclusively on the scalp, whereas body lice live on clothing and only move to the skin to feed $[10,12,13]$. This ecological differentiation arose when humans adopted frequent use of clothing [14]. In addition, molecular studies [15,16] confirm that head and body lice are conspecific, despite their differences. This point raises the first question: what subspecies is used as a medical remedy for jaundice? In 1929 Gárate [17] wrote: “... D. Miguel de Unamuno told me that several Pediculi capitis were poured into a glass, were crushed and water was added..." Subsequently, in 1972, Donostia clarifies that "live lice, taken from a clean and disease free head" are used [18]. These two direct references are sufficient to exclusively consider the use of head lice for the treatment of jaundice.

The life cycle of the head louse has three stages: egg, nymph, and adult. Adults are small (2.1-3.3 mm long), dorso-ventrally flattened and entirely wingless. Females can lay about 7 eggs per day, gluing nits to the base of human hair. To survive, adult lice need to feed on blood several times daily $[10,12,13]$.
The objective of this paper is to collect in one document all traditional remedies used against jaundice based on the intake of adult head lice within the realm of Spanish folk medicine. These remedies, just as for other animal species, are scattered among countless references (many of which are inaccessible to the general public). It also analyzes the validity and geographical distribution of this therapeutic resource in Spain, and its relationship with the traditional medicine of other cultures.

\section{Methods}

To get the maximum number of documentary sources, a qualitative systematic review of international and national databases was carried out. The international databases ISI Web of Science and Anthropology Plus were consulted. Domestic resources that were referenced include the database of Doctoral Theses TESEO, databases of the information system of Consejo Superior de Investigaciones Científicas (CSIC) and bibliographic web Dialnet. The overall search pattern covered the title, abstract and key words concerning ethnozoology related disciplines that have UNESCO codes (e.g., anthropology, history of medicine, zoology, entomology) and terms louse (lice), jaundice, folk medicine, folklore, digestology, ethnozoology, zootherapy and entomotherapy, in conjunction with the Spanish geographical scope. In turn, all related works systematically obtained were checked for recording data on the use of head lice as a remedy for jaundice.

\section{Results}

A total of 33 studies were reviewed from the literature search. Table 1 provides a list of references consulted (arranged chronologically). The original descriptions of the remedies are included, and the geographical location of the use is indicated.

\section{Validity}

The therapeutic use of head lice against jaundice has remained in Spanish oral tradition and has survived until today, although its current use has not been documented in research within the last decade.

\section{Method of preparation and dosage}

In 9 studies (27\%) the necessary intake of live lice is documented. It is a transference therapy based on the belief that these insects feed on bile, which is the materialization of the "disease" [18,25,50].

Many references indicate that lice should be administered to the patient on an empty stomach without his/ her knowledge. They are usually dissolved or mixed in food that the patient has to take. A wide range of food is mentioned and chocolate is especially recommended. 
Table 1 List of Spanish traditional remedies for jaundice based on the ingestion of head lice

\begin{tabular}{|c|c|}
\hline References & Method of preparation and dosage \\
\hline Morán Bardón, 1927 [19] & $\begin{array}{l}9 \text { lice are put into the patient's lunch } \\
\text { over the course of } 9 \text { days without his/her } \\
\text { knowledge. They can be put into soup, an } \\
\text { omelette or chocolate }\end{array}$ \\
\hline Gárate, 1929 [17] & $\begin{array}{l}\text { Treatment consisting of ingesting lice (I was } \\
\text { not told whether the lice were alive or not) }\end{array}$ \\
\hline Risco and Rodríguez Martínez, 1933 [20] & Take lice. They forced the patient to take 9 lice \\
\hline Iribarren, 1943 [21] & $\begin{array}{l}\text { Some healers prescribe taking a handful of } \\
\text { lice or eating live lice with bread }\end{array}$ \\
\hline Caro Baroja, 1944 [22] & $\begin{array}{l}\text { An extremely disgusting procedure: take a } \\
\text { variable number of lice }\end{array}$ \\
\hline Marcos de Sande, 1947 [23] & Ingest 7 live lice in a piece of bread \\
\hline Díaz Mora, 1948 [24] & $\begin{array}{l}\text { The patient was administered } 3 \text { crushed lice } \\
\text { dissolved in "aguardiente" (liqueur) or urine. } \\
\text { In Gata the number of parasites ingested for } \\
\text { correct treatment is } 16\end{array}$ \\
\hline Lis Quibén, 1949 [25] & $\begin{array}{l}\text { Ingest lice. In Cotovad, for } 9 \text { days, they give } \\
\text { the patient on an empty stomach a glass of } \\
\text { wine with } 9 \text { lice that were left outside in the } \\
\text { cold the night before. In Cambados, the patient } \\
\text { eats dead lice in a broth or alive in bread. In } \\
\text { Verín, they give the patient the noted } 9 \text { lice } \\
\text { in milk or chocolate }\end{array}$ \\
\hline
\end{tabular}

Geographical location

Salamanca province

Bilbao (Biscay); Deva, Villabona (Guipúzcoa)

Melide (La Coruña)

Uitzi, Pamplona (Navarre)

Vera de Bidasoa (Navarre)

Garrovillas (Cáceres)

Valverde del Fresno, Eljas, Gata (Cáceres)

Verín (Orense); Cotovad, Cambados (Pontevedra)

Cornellana (Salas, Asturias)

Santa Justa-Moraña (Pontevedra)

Verín (Orense)

Asturias

Amaiur (Navarre)

Put 5 live lice, taken from a clean and disease free head, in the heart of an apple or in a piece of bread and eat them. If 5 is not enough, the next time 7 lice are used

Barandiarán, 1974 [30]

Barriola, 1979 [31]

They say that to cure jaundice it is necessary to ingest lice

Lice should be administered without patient knowledge, in chocolate, wine or liquor, soup, or a corn silk infusion

Becoña Iglesias, 1981 [32]

The patient should take lice without his/her knowledge. The quantity to be taken was 3 or 4 lice, once or twice. They were given in water or milk

Carril, 1981 [33]

They gave the affected person without his/her knowledge, 9 lice for 9 consecutive days at breakfast or lunch

Goicoetxea Marcaida, 1983 [34]

Blanco, 1985 [35]

Junceda Avello, 1987 [36]

Martí i Pérez, 1988 [37]

Vázquez Gallego, 1989 [38]
The patient should ingest lice, better living, taking them with liquor, chocolate or the decoction of corn silk

Pour lice into broth; eat lice

A disgusting recipe: take 9 lice for 9 days. Eat 9 lice together with vegetables

Ingest live lice mixed with some food

While fasting, give the patient over the course of 9 days, a glass of wine with 9 lice that were left outside in the cold the night before
Basque Country

Basque Country

A Comboa, Estribela, Rorís (Pontevedra)

Salamanca province

Amorebieta, Elorrio, Zeanuri (Biscay); Olaeta (Álava); Irún (Guipúzcoa)

El Arco, Negrilla de Palencia, Robleda (Salamanca)

Asturias; Galicia

Dosrius, Barcelona city (Barcelona); Blanes (Gerona)

Galicia 
Table 1 List of Spanish traditional remedies for jaundice based on the ingestion of head lice (Continued)

Barandiarán, 1990 [39]
Mateos Romero, 1990 [40]
Rúa Aller and Rubio Gago, 1990 [41]
Carril, 1991 [42]
Guío Cerezo, 1992 [43]
Fresquet, 1995 [44]

Pámpano and Redondo, 1997 [45]

Erkoreka, $2002[46]$

Álvarez Peña, 2004 [47]

Barandiarán and Manterola, 2004 [48]

Álvarez Caperochipi, 2012 [49]
It is necessary to eat lice. The patient should drink water in which 7 head lice were previously cooked

For 3 days, eat soup prepared with oil previously used to fry 8 or 10 lice. The patient should not know the origin of the recipe

Drink water in which lice had been cooked

Drink a lice decoction

Put lice into a fig and eat it

Some people gave children a drink made of white wine with lice, cinnamon and sugar

9 live lice are eaten mixed with flour, honey and sugar. Afterwards, a diet of varied stocks should be followed

Live lice should be added to porridge, chocolate, coffee or other food to be taken by the patient without his/her knowledge

Swallow live lice with milk or butter

\begin{abstract}
In Amorebieta, Bera and Elorrio, in the first decades of the 20th century, it was necessary to give the patient several lice in a small cup of chocolate or mixed with liquor without his/her knowledge: 7, 9, 11,13 , always an odd number. The same remedy was applied in Zeanuri and Olaeta, where lice were introduced into soup, and Quintana where they were placed in the patient's ordinary food without his/her knowledge. In villages far from the coast for several days, the patient was given a tisane in which 9 lice were placed or they were mixed with some food eaten regularly. Our current surveys have also collected this remedy. In Bermeo and Hondarribia live lice were added to porridge, chocolate, coffee or other food that should be eaten by the patient without his/her knowledge. In Orozco the lice were eaten in an omelette
\end{abstract}

At the beginning of the XX century, many healers applied dried head lice dissolved in water. They crushed the lice in a glass and then added water. They would give a drop to the patient and if he/she felt good they would give the patient two drops the following day. The dosage would be increased daily by one drop each day up to 21 drops to then be decreased
Basque Country

Torremenga (Cáceres)

Comarca de El Bierzo (León)

Fuenteguinaldo (Salamanca)

Llerena (Badajoz)

Comarca de la Ribera Alta (Valencia)

San Vicente de Alcántara (Badajoz)

Basque Country

Deva (Gijón) and other councils from Asturias

Amorebieta, Bermeo, Elorrio, Orozco, Zeanuri (Biscay); Olaeta, Quintana (Álava); Hondarribia (Guipúzcoa); Bera (Navarre)

Ilarregui and other villages from Navarre
With regard to the dosage, 16 studies (48\%) indicate the number of lice to ingest. In most cases, odd numbers are mentioned; in nine the recommended number is 9. This is the same amount that appears most often as the recommended number of days for treatment duration (9 days). In Spanish popular culture, the odd are laden with symbolism and considered to be sacred in character, thus, they form part of healing rituals. The number 9 is considered as "the perfection" and a symbol of life [51].

\section{Geographical distribution}

As for the geographical distribution of the use of head lice as a remedy for jaundice, appointments found cover much of the northwestern quadrant of Spanish territory
(Figure 1). Numerous localities in the Basque Country and Navarre are mentioned.

Numerous authors show that using animal resources as therapy is a widely distributed atavistic practice $[52,53]$, a fact that is demonstrated by the use of head louse against jaundice in distant geographical areas [54,55]. Its use is particularly common in the Hebrew culture. Izaak Walton in his famous book "The Compleat Angler" (published in 1653) records that the Jews were the first to say that swallowing live lice is a good remedy for jaundice [56]. For their part, the German rabbi Yair Bacharach (1639-1702), author of the collection of responsa known as "Havvot Yair" ("Villages of Yair"), indicates that the patient should take 8 lice taken 


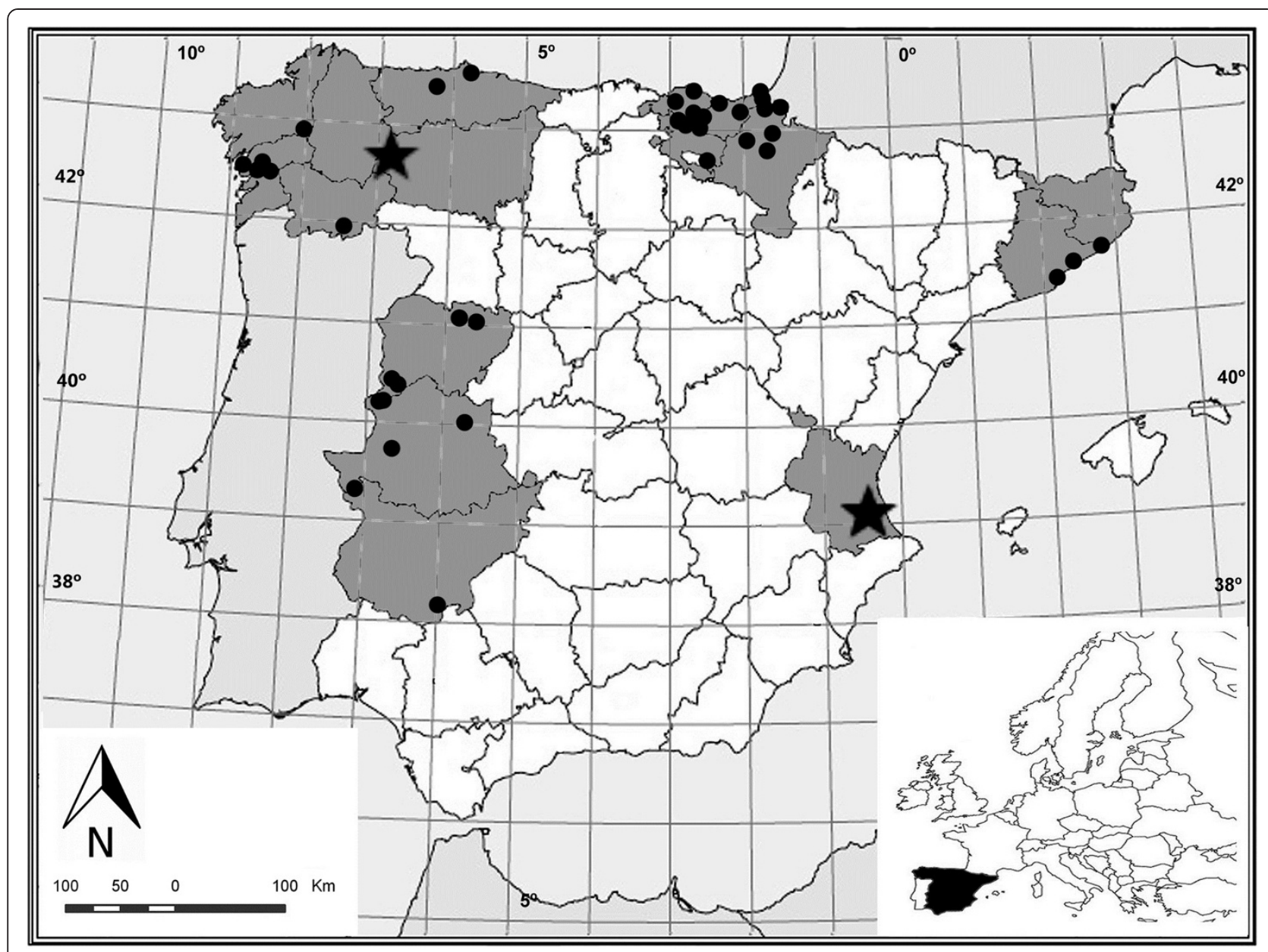

Figure 1 Geographical distribution of the use of head lice as an anti-jaundice remedy in Spain. The cited provinces and autonomous communities are highlighted in gray; $(\bullet)$ mentioned localities; $(\boldsymbol{\star})$ "comarcas" ( $\sim$ regions, shires).

from his/her own head-see Rosner and Bleich 2000 [57]. Ben-Ezra in 1949 recorded in Horodetz (one of the oldest Jewish communities in Russia-Poland) the introduction of lice in an omelette as treatment [58]. In Latin America there are also references to this medical practice. In this case, the remedy would have been brought by the Spanish conquistadors and assimilated by the Spanish American folk medicine in an eclectic form [9]. The recommended number of specimen to take in Chile, Peru, Guatemala and Argentina is 4 or 5 with examples found using measures such as a thimbleful [59-62].

\section{Discussion}

The key elements of Spanish folk medicine can be found in beliefs and empiricism [50,63], thus the employed remedies and recipes have been developed primarily through magical conceptions using the homeopathic principle similia similibus curantur or following the natural-philosophical basis of the humoral theory [64]. Keep this in mind, and although the explanations and justifications for taking head lice as an anti-jaundice remedy are complex, it can be hypothesized following two arguments. First, an Aristotelian scheme of thought like Bartholomaeus Anglicus (born before 1203-died 1272) can be used as a starting point. Anglicus applied the humoral theory to the origin of human louse and proposed a hypothesis with a magical explanation of homeopathic type. In chapter LXXXII of his compendium De proprietatibus rerum ("On the Properties of Things"), this author wrote: "lice are begotten of rotten humours that are between the skin and flesh, and fall outside with the sweat"-see Seymur 1975-1988 [65]. Furthermore he classifies them, stating that "those who are begotten from the choleric humour are greenishyellow". Choleric humour is synonymous of yellow bile, hence following the principle similia similibus curantur these ectoparasitic insects can be considered a remedy for the treatment of jaundice. This type of reasoning, based on a magical explanation (without rational basis), has been important in therapy throughout history and 
was highly valued by Classical Greek philosophers such as Empedocles or Plato [66,67]. Second, folk medicine users also create their own conceptions about health by developing theories with rational bases. For example, in the early 20th century in the Basque Country people still thought that a web in the liver or stomach prevented the normal circulation of bile making it necessary to drill or destroy it. For this reason, the basis of curative applications lies in the belief that the patient should ingest live lice to either break the web or eat it [34,48]. In Navarre it was explained that when the lice reached the initial part of the intestine they would cause a reaction and help release retained bile [49]. These popular explanations coincide with the description given by Sterpellone [68], who presumed that: “... swallowed lice reaches the stomach and, as they are resistant to the action of gastric juices, pass through the pylorus and enter the duodenum, tickling the walls. This tickle causes contractions in the duodenal wall favouring bile flux and relieving bile stasis which causes jaundice when the bile ducts are blocked due to a mucous stopper."

In Early Modern history lice intake was described as a "superstitious remedy", i.e. as a misconception and not accepted by official medicine, which considered it an "illegitimate knowledge". Despite all, this remedy, typical of oral tradition, has been passed on to us (see Table 1).

At present, folk medicine makes use of the Information and Communication Technology for the transmission and dissemination of knowledge. It is interesting to note that inquiries related to this folk remedy appeared on various websites relating to health and disease management (www. home-remedies-for-you.com, www.medicalfaq.net) in June 2008. The question posed by a user was as follows: "Can head lice given to a person reduce extreme jaundice? Is it true? Please, advise me." As expert, G M (on June 12, 2008) responded: "I have never heard of any such treatment for jaundice involving head lice. Preferring 'natural' cures has its place, but everything that is natural is not necessarily good" (see http://www.home-remedies-for-you. com/askquestion/18048/jaundice-treatment-and-diet-helpcan-head-lice-giv.html). The previous question and answer reflect popular conceptions about health and disease. Considering that this remedy has been part of our collective knowledge and cultural background, we can state that it is part of a deeply rooted "implicit theory". Therefore, although the remedy is not currently used in Spain, it is necessary to consider how these ideas have influenced the behaviour of the patients, how they cope with the disease and how to address medical pluralism.

Moreover, this work lies within the context of ethnomedicine and insects, the latter being an animal group of great therapeutic potential. In recent years there have been regularly published reports addressing their importance in the search for new drugs [69-71] and even the pharmacological properties of certain species [72-74] or insect-derived products $[75,76]$ have been studied. Thus, the present document should serve as a basis and a valuable tool for future chemical screening and biological assays, and should open new perspectives for the economic and cultural assessment of animals traditionally thought of as being of no use.

\section{Conclusions}

The use of folk remedy for jaundice based on the ingestion of head lice is difficult to understand due to lack of information on sympathetic or antipathetic associations that were established in the past. However, the survival of this traditional knowledge in Spanish society and its relatively wide geographical distribution helps verify the consistency of the theories formulated within rural communities, even though they may conflict with biomedical health care. It also suggests the need of taking into account the beliefs, ideas and behaviour patterns of popular culture in relation to health and disease for a better understanding with the patient.

\section{Competing interests}

Both authors declare that they have no competing interests.

\section{Authors' contributions}

The two authors contributed equally during the data collection, data analysis and preparation of the manuscript, and read and approved the final manuscript.

\section{Acknowledgements}

We would like to thank Anne Sherman for her English technical support.

\section{Author details}

${ }^{1}$ Departamento de Terapéutica Médico-Quirúrgica, Facultad de Medicina, Universidad de Extremadura, E-06006, Badajoz, Spain. ${ }^{2}$ Grupo de Investigación de Recursos Etnobiológicos del Duero-Douro (GRIRED), Facultad de Biología, Universidad de Salamanca, E-37071, Salamanca, Spain.

Received: 15 May 2013 Accepted: 20 July 2013

Published: 22 July 2013

\section{References}

1. Costa-Neto EM: Entomotherapy, or the medicinal use of insects. J Ethnobiol 2005, 25(1):93-114.

2. Costa-Neto EM, Ramos-Elorduy J, Pino JM: Los insectos medicinales de Brasil: primeros resultados. Boln SEA 2006, 38:395-414

3. Chakravorty J, Ghosh S, Meyer-Rochow VB: Practices of entomophagy and entomotherapy by members of the Nyishi and Galo tribes, two ethnic groups of the state of Arunachal Pradesh (North-East India). J Ethnobiol Ethnomed 2011, 7:5.

4. Meyer-Rochow VB: Ethno-entomological observations from North Korea (officially known as the "Democratic People's Republic of Korea"). J Ethnobiol Ethnomed 2013, 9:7.

5. Arese P, Gallo V, Pantaleo A, Turrini F: Life and death of glucose-6-phosphate dehydrogenase (G6PD) deficient erythrocytes - role of redox stress and band 3 modifications. Transfus Med Hemother 2012, 39:328-334.

6. Tan CB, Rashid S, Rajan D, Gebre W, Mustacchia P: Hepatic sarcoidosis presenting as portal hypertension and liver cirrhosis: case report and review of the literature. Case Rep Gastroenterol 2012, 6:183-189.

7. Wang YX, Liu H: Adult hepatoblastoma: systemic review of the English literature. Dig Surg 2012, 29:323-330.

8. Blánquez A: Aurelio Cornelio Celso. Los ocho libros de la Medicina. Iberia: Barcelona; 1966. 
9. Foster GM: Relationships between Spanish and Spanish-American folk medicine. J Am Folklore 1953, 66(261):201-217.

10. Durden LA, Lloyd JE: Lice (Phthiraptera). In Medical and Veterinary Entomology. 2nd edition. Edited by Mullen GR, Durden LA. Amsterdam: Academic Press; 2009:59-82.

11. Bisby F, Roskov Y, Culham A, Orrell T, Nicolson D, Paglinawan L, Bailly N Kirk P, Bourgoin T, Baillargeon G, Hernández F: Species 2000 \& ITIS Catalogue of Life, 18th April 2013. 2013. www.catalogueoflife.org/col/ details/species/id/6850820.

12. Lehane MJ: The Biology of blood-sucking in insects. 2nd edition. Cambridge: Cambridge University Press; 2005

13. Meinking TL: Human lice. In Encyclopedia of Entomology. 2nd edition. Edited by Capinera JL. Heidelberg: Springer; 2008:1883-1886.

14. Kittler R, Kayser M, Stoneking M: Molecular evolution of Pediculus humanus and the origin of clothing. Curr Biol 2003, 13:1414-1417.

15. Leo NP, Campbell NJH, Yang X, Mumcuoglu K, Barker SC: Evidence from mitochondrial DNA that head lice and body lice of humans (Phthiraptera: Pediculidae) are conspecific. J Med Entomol 2002, 39(4):662-666.

16. Li W, Ortiz G, Fournier PE, Giménez G, Reed DL, Pittendrigh B, Raoult D: Genotyping of human lice suggests multiple emergences of body lice from local head louse populations. PLoS Negl Trop Dis 2010, 4(3):e641.

17. Gárate J: Los estudios de medicina en el País Vasco. Rev Int Estud Vascos 1929, 20(3):378-396.

18. Donostia JA: Oraciones, prácticas religiosas y medicinas populares. CEEN 1972, 10:5-34.

19. Morán Bardón C: Creencias sobre curaciones supersticiosas recogidas en la provincia de Salamanca. AMSEAEP 1927, 6:241-261.

20. Risco V, Rodríguez Martínez A: Folklore de Melide. In Terra de Melide. Edited by W AA. Santiago de Compostela: Seminario de Estudos Galegos Nós; 1933:456-457.

21. Iribarren JM: Batiburrillo navarro: segunda parte de Retablo de Curiosidades. Zaragoza: Imprenta Heraldo de Aragón; 1943.

22. Caro Baroja J: La vida rural en Vera de Bidasoa (Navarra). Madrid: Instituto Antonio de Nebrija-CSIC; 1944.

23. Marcos De Sande M: Del folklore garrovillano. Rev Est Extremeños 1947 1-2:77-114.

24. Díaz Mora R: La región natural de la Sierra de Gata, Iniciación al estudio de su folklore con especial mención de su medicina popular. PhD thesis. Madrid: Universidad Complutense de Madrid; 1948.

25. Lis Quibén V: La Medicina Popular en Galicia. Pontevedra: Gráficas Torres; 1949.

26. Arias MA: La leyenda de San Salvador de Cornellana. Bol Inst Estud Asturianos 1955, 25:269-282.

27. Duran Sotelo A: Algunos aspectos de la vida en Santa Justa (Moraña). Degree thesis. Santiago de Compostela: Universidad de Santiago de Compostela; 1961.

28. Taboada J: Folklore de Verín: las creencias y el saber popular, Volume 2. Orense: La Región; 1961.

29. Fernández-Ruiz C: Historia médica del Principado de Asturias. Oviedo: Instituto de Estudios Asturianos: 1965.

30. Barandiarán JM: Obras completas. Gran Enciclopedia Vasca, vol. 6. Gobierno Vasco: Bilbao; 1974

31. Barriola IM: La medicina popular en el País Vasco. San Sebastián: Ediciones Vascas; 1979

32. Becoña Iglesias E: La actual medicina popular gallega. 2nd edition. La Coruña: Magoygo; 1981

33. Carril A: Veterinaria y medicina popular en Salamanca. Rev Folklore 1981 5:27-32.

34. Goicoetxea Marcaida A: Capítulos de la Medicina Vasca. Salamanca: Instituto de Historia de la Medicina, Universidad de Salamanca; 1983.

35. Blanco JF: Medicina y veterinaria populares en la provincia de Salamanca. 2nd edition. Salamanca: Diputación de Salamanca; 1985

36. Junceda Avello E: Medicina popular en Asturias. Oviedo: Instituto de Estudios Asturianos; 1987

37. Martí i, Pérez J: La medicina popular en Cataluña. Anthropologica 1988 3:69-89.

38. Vázquez Gallego X: Tradiciones, mitos, creencias y curanderismo en medicina popular de Galicia. Lugo: Diputación Provincial de Lugo; 1989.

39. Barandiarán JM: Recetas y remedios en la tradición popular vasca. San Sebastián: Txertoa; 1990.

40. Mateos Romero T: Estudio antropológico-médico de Torremenga (Cáceres). Cáceres: Institución Cultural "El Brocense"-Diputación de Cáceres; 1990.
41. Rúa Aller FJ, Rubio Gago ME: La medicina popular en León. León: Ediciones Leonesas; 1990

42. Carril A: Etnomedicina. Acercamiento a la terapéutica popular. Castilla Ediciones: Valladolid; 1991.

43. Guío Cerezo Y: Naturaleza y Salud en Extremadura: Ios remedios. Mérida: Asamblea de Extremadura; 1992.

44. Fresquet $J \mathrm{~L}(\mathrm{Ed})$ : Salud, enfermedad y terapéutica popular en la Ribera Alta. Valencia: Instituto de Estudios Documentales e Históricos sobre la Ciencia, Universitat de València-CSIC; 1995.

45. Pámpano M, Redondo F: Remedios caseros para dolencias. In San Vicente de Alcántara. Coordinated by Briegas Caro JM. San Vicente de Alcántara (Badajoz): Círculo Recreativo; 1997:99-122.

46. Erkoreka A: Análisis de la medicina popular vasca. Barcelona: Bibliotex; 2002.

47. Álvarez Peña A: Magic-traditional medicine in Asturias (in Asturian language). Gijón (Asturias): VTP Editorial; 2004.

48. Barandiarán JM, Manterola A (Eds): Medicina popular en Vasconia. Bilbao: Instituto Labayru; 2004.

49. Álvarez Caperochipi J: Curanderismo y medicina popular en el entorno de Navarra. Pamplona: Evidencia Médica; 2012.

50. Kuschick I: Medicina popular en España. Madrid: Siglo XXI de España Editores; 1995.

51. Gavilanes E: El número nueve en la medicina popular. RDTP 1995, 50(1):243-261.

52. Lev E: Traditional healing with animals (zootherapy): medieval to present-day Levatine practice. J Ethnopharmacol 2003, 86:107-118.

53. Alves RRN, Rosa IL: Why study the use of animal products in traditional medicines? J Ethnobiol Ethnomed 2005, 1:5.

54. Radford E, Radford MA: Encyclopedia of Superstitions, Edited and revised by Christina Hole. London: Hutchinson; 1961.

55. Martin EB: They're killing off the rhino. Natl Geogr 1984, 165(3):404-422.

56. Walton I: El perfecto pescador de caña. Barcelona: Gráficas Marsá; 1955.

57. Rosner F, Bleich JD: Jewish Bioethics. Hoboken NJ: KTAV Publishing House; 2000

58. Ben-Ezra A: Horodetz: history of a town, 1142-1942. New York: "Horodetz" Book Committee; 1949

59. Vicuña Cifuentes J: Mitos y supersticiones. Santiago de Chile: Nascimento; 1945

60. Villatoro E, Reyes O: Guatemala: Mesoamérica y occidente, 500 años de simbolismos y prácticas médicas. Tradic Guatem 1992, 37-38:47-59.

61. Alarco De Zadra A: Nuestra fauna: comentarios, acerca de 521 ejemplares. Lima: Sociedad Geográfica de Lima; 1997.

62. Nario H: Los Picapedreros. Tandil: Ediciones del Manantial; 1997.

63. Mariño Ferro XR: Los dos sistemas de la medicina tradicional y sus claves. In Creer y curar: La medicina popular. Edited by González Alcantud JA, Rodríguez Becerra S. Granada: Diputación Provincial de Granada; 1996:421-456.

64. Leonti M: The future is written: Impact of scripts on the cognition, selection, knowledge and transmission of medicinal plant use and its implications for ethnobotany and ethnopharmacology. J Ethnopharmacol 2011, 134:542-555.

65. Seymur MC (Ed): On the Properties of Things. John Trevisa's translation of Bartholomaeus Anglicus, De proprietatibus rerum: A critical text (3 vols.). Oxford: Clarendon Press. 1975-1988.

66. Cohen M: Poder Curar. Buenos Aires: Del Signo; 2004.

67. Laín Entralgo P: La curación por la palabra en la Antigüedad clásica. Rubí (Barcelona): Anthropos; 2005.

68. Sterpellone L: Historias curiosas de la Medicina. Barcelona: Robinbook; 2009.

69. Cherniack EM: Bugs and drugs: part 1: Insects. The "new" alternative medicine for the 21st century. Altern Med Rev 2010, 15(2):124-135.

70. Dossey AT: Insects and their chemical weaponry: New potential for drug discovery. Nat Prod Rep 2010, 27:1737-1757.

71. Ratcliffe NA, Mello CB, García ES, Butt TM, Azambuja P: Insect natural products and processes: New treatments for human disease. Insect Biochem Molec Biol 2011, 41(10):747-769.

72. Huberman L, Gollop N, Mumcuoglu KY, Block C, Galun R: Antibacterial properties of whole body extracts and haemolymph of Lucilia sericata maggots. J Wound Care 2007, 16(3):123-127.

73. Coutinho HDM, Vasconcellos A, Lima MA, Almeida-Filho GG, Alves RRN: Termite usage associated with antibiotic therapy: enhancement of aminoglycoside antibiotic activity by natural products of Nasutitermes corniger (Motschulsky 1855). BMC Complement Altern Med 2009, 9:35.

74. Gunbilig D, Boland W: Defensive agents of Blaps femoralis, a traditional Mongolian medicinal insect. Sci Pharm 2009, 77:597-604. 
75. Son DJ, Lee JW, Lee YH, Song HS, Lee CK, Hong JT: Therapeutic application of anti-arthritis, pain-releasing, and anti-cancer effects of bee venom and its constituent compounds. Pharmacol Ther 2007, 115(2):246-270.

76. Viuda-Martos M, Ruiz-Navajas Y, Fernández-López J, Pérez-Álvarez JA: Functional properties of honey, propolis, and royal jelly. J Food Sci 2008, 73(9):117-124

doi:10.1186/1746-4269-9-52

Cite this article as: Vallejo and González: The use of the head louse as a remedy for jaundice in Spanish folk medicine: an overview. Journal of Ethnobiology and Ethnomedicine 2013 9:52.

\section{Submit your next manuscript to BioMed Central and take full advantage of:}

- Convenient online submission

- Thorough peer review

- No space constraints or color figure charges

- Immediate publication on acceptance

- Inclusion in PubMed, CAS, Scopus and Google Scholar

- Research which is freely available for redistribution 